\title{
Adversity of industrial water pollution on agriculture and livelihood: Experiences of rural population of Dindigul
}

\section{Srinivasan Kannan PhD ( $\sim$ ksrini@sctimst.ac.in )}

Sree Chitra Tirunal Institute for Medical Sciences and Technology, Trivandrum

Rengasamy Karuppaiah MBA PhD

Sree Chitra Tirunal Institute for Medical Sciences and Technology, Trivandrum

\section{Research Article}

Keywords: Tannery Pollution, Dindigul, drinking water contamination, poor agricultural production, polluted irrigation, soil infertility, poor livelihood

Posted Date: August 16th, 2021

DOI: https://doi.org/10.21203/rs.3.rs-817561/v1

License: (c) (i) This work is licensed under a Creative Commons Attribution 4.0 International License.

Read Full License 


\section{Abstract}

Tannery pollution affected water and livelihood of people in Dindigul. Polluted water and soil reduced agricultural production; contaminate drinking water, and livelihood. The present study aims to study the adverse effects of industrial pollution on agriculture and livelihood in Dindigul. Twenty randomly villages drawn with equal number from the vicinity of tanneries and far. A survey was conducted using structured interview schedule among 400 men and women of 18 years and above from 20 villages. Details on Socio-Economic characteristics, water, agriculture and livelihood collected online using Kobo toolbox in Tamil language. In affected and non-affected villages 71 and 102 hold agricultural land only 53 and 87 have cultivated respectively. One third in affected villages and two thirds in non-affected villages cultivated throughout the year. Tanneries affected the livestock population, reduced agricultural production, polluted irrigation, polluted soil and made it infertile, deteriorated the quality of agricultural produce. Compared to economic benefits from tanneries the damage are exorbitant. Politicians and policy makers ignored pollution and turned blind eye to the problems caused to the rural population and livelihood.

\section{Introduction}

Water resources are lifelines to the ecosystem and society. According to World Economic Forum, for sustainable development one of the concerns along with forest loss, land conversion, decline in species and climate change was water stress(Agenda 2016). Clean water supply is one of the determinants of social wellbeing. Water is also a factor of production in agriculture. Use and abuse of water cause scarcity of water, reduction in agricultural production and affect the livelihood of the population. Excess fresh water consumption and pollution due to human activities pressurises availability of water and impact food security, environmental quality, economic development, and social wellbeing(Ercin 2018). Scarcity of fresh water will be aggravated in future due increase in demand for water and decrease in availability and quality(Ercin 2018). That will also cause problems in food security and environmental sustainability(Ercin 2018). According to World Economic Forum world risk report, 2016, India reported reduction in crop yield by around $20 \%$ (Klaus 2016). To add to the water stress, the rampant industrial pollution contaminates the limited available water resources(Schulte and Morrison 2014). The water stress on the water sources, adversely affects the environment and livelihood of the population.

Reduction in the limited available water leads to serious economic loss(Meier 1977). The substantial monetary burden on rural communities is caused by industrial pollution(Reddy and Behera 2006). The livelihood of rural dwellers was greatly affected as the effluents from the industries damaged their water resources(Oluseyi, Oluseun, and Birdie 2011) by adversely impact on environmental biotic and abiotic factors(Shah, SN. Manzoor, S. and Asim 2021). Water also contributes to social capital in communitybased irrigation, drinking water delivery systems(Kähkönen 1999). The industries dump the solid waste in an open area and discharge untreated wastewater that in turn negatively affects the health of the households and environment(Mamuye Bayu 2018). This is not only applicable to larger industries even the small rural industries pollutes rivers and make the water unsafe for human consumption(Wang et al. 
2008). Larger corporations such as Cracker and Polymer industries pollute rivers that impact the health, lives and livelihood of the population who live near rivers(Mech and Hazarika 2018). Industrial wastewater pollution along with municipal wastewater contaminates the water in the rural areas with heavy metals and that in turn affect agriculture, aquaculture, livestock drinking, and recreational activities(Mekuria, Kassegne, and Asfaw 2021). In addition, the river also had to deal with fertilizer use water pollution(Zhou, Li, and Huang 2021). The pesticide pollution in water systems was above permitted levels affecting the health of the population(Veiga et al. 2006). People who use polluted surface water sources for drinking, cooking, bathing and clothes washing increases the risk of diarrheal diseases and stunting among children(Kulinkina et al. 2020). This makes children engage in the collection of water and that affects their education(Choudhuri and Desai 2021). To address the problem we have to integrate social and physical science for water management(Lund 2015). The experience of the efforts made in the budget-constrained environment was found not feasible(Shortle et al. 2012). So it is important to consider social responses in environmental and water resources planning(Walker, Loucks, and Carr 2015). Otherwise, this will lead to conflicts during the water collection between the inhabitants and also within the households(Mallick and Fernanda Roldan-Rojas 2015). Water pollution should be given the same level of importance similar to that of air pollution(Fu, Cao, and Tong 2020).

In the town of Dindigul, Tamil Nadu in South India, Kudaganaru river was found to be polluted by 17 tanneries by discharging their effluents and affecting 15 villages who depend on the river was raised by the community initiatives demanding water rights(Trust, n.d.). There were efforts by the Legal institutions such as Supreme Court of India by establishing 'Lost of Ecology Authority' in 1996 and subsequent legal battles by the villagers on insufficient compensation and judgement by the Madras High Court were suggestive of unending problems faced by the rural population(Asha 2002). Both the Apex court and the State Court were based their arguments emphasizing on "precautionary principle" and the "polluter pays" was to be implemented by the 'Lost of Ecology Authority' established for this purpose(Court 2014). There were efforts by the State Pollution Control board by establishing Common Effluent Treatment Plant through an agency since 1997 and it was fully functional from March 2012. There were already 49 tanneries joined with the agency for treatment(TNSPCB, n.d.). From the above it is clear that tannery pollution adversely affects both the health of the population and the environment. The Pollution of water further, pollutes the soil and reduces agricultural production, making the drinking water contaminated, and also disturbs the livelihood of the population. The present study aims to study the adverse effects of industrial pollution on agriculture and livelihood of the population of Dindigul district, South India.

The paper specifically would like to study the experiences of the rural population on the difficulties faced due to industrial pollution through its effect on water, agriculture and livelihood of the population live in around the tanneries in Dindigul.

\section{Material And Method}

The study was conducted in the villages of Dindigul district which is known for its tannery industries. Ten villages each were drawn randomly from the vicinity of tanneries and far from tanneries. Following 
explanatory design a survey using a structured interview schedule was conducted among the men and women above 18 years from the selected villages of Dindigul, district. Questions on Socio-Economic details, the effect of industrial pollution on water, agriculture and livelihood were administered on the respondents. The villages close to tanneries were named as affected villages and the villages that were located more than 10 Kilometres away from the tanneries were named as non-affected villages. The villages that are away from tanneries too had industries other than tanneries, such as textile and so on. Those villages were included to compare the impact of industries of tanning and other sectors. In total there were 400 respondents from 20 villages were randomly selected. The affected villages were drawn from the total of 21 Panchayats randomly. The 21 Panchayats were drawn from 4 randomly drawn Blocks and those Blocks were randomly drawn from the randomly drawn 3 Tauks from the one out of two Divisions. Similarly, the non-affected villages were drawn from the total of 15 Panchayats randomly. The 15 Panchayats were drawn from 2 randomly drawn Blocks and those Blocks were randomly drawn from the randomly drawn 2 Tauks from the one out of two Divisions.

One village was selected randomly for both the affected and non affected villages from each selected Panchayat. For each of the village, one or two wards were selected based on the criteria developed after the preliminary field assessment based on a visit to the tanneries. The voters' lists of all the 20 villages were downloaded from the election commission website(Commission, n.d.) and the samples were drawn for data collection. The separated male and female voters list for the selected villages were prepared and this was used to draw 10 male and 10 female respondents for data collection using an online random table(Random.org, n.d.). Online form for data collection using a Tablet based on the Kobo toolbox was developed. The tool was tested during the pilot phase by the Research Associate. Two trained field investigators collected the data during three month period starting from December 2020. Data were analysed using SPSS 21. The Ethical clearance for the study was obtained from the Institute Ethics Committee of Sree Chitra Tirunal Institute for Medical Science and Technology, Trivandrum (SCT/IEC/1495/Ocober-2019). The participants who have voluntarily consented were included for the study. The participant information sheet and informed consent form in the Tamil language were shared with the respondents and only the consented respondents were included in the study. The detailed methodology was published elsewhere(Kannan 2020).

\section{Results}

\subsection{Socio-demographic characteristics of respondents}

\subsubsection{Economic characteristics of respondents}

As intended to have equal numbers of males and females both in affected and non-affected villages, there were 200 male and 200 female respondents. The mean age of the respondents was 44.83(Range21$87, S D \pm 0.705$ ). The mean income was INR 5160 (Range 4695 - 5624, SD 4724). There was a slight difference between mean income of affected and non-affected villages (INR5449 and INR4871). In the affected villages, 47 respondents worked for the Mahatma Gandhi National Rural Employment Guarantee 
Scheme, 47 were agricultural/construction workers, 31 respondents were engaged in other service jobs, 30 respondents owned micro level enterprises, 21 were at home as they were housewives or retired or elderly or students. There were 18 farmers, 13 livestock breeders, and 2 were unemployed. Similarly, in the non-affected villages, more than 63 of them were agricultural/construction workers, 56 were engaged in Mahatma Gandhi National Rural Employment Guarantee Scheme and 52 were farmers. There were 25 livestock breeders, 22 were at home as they were housewives or retired or elderly or students and 20 were engaged in other service jobs, 8 engaged owned micro level enterprises, and 4 were unemployed. It is important to note that most of them were engaged in multiple professions in different part of the year as the activities are seasonal in nature. In terms of ration card type an indicator of poverty status, $67 \%$ of the respondents were holding below poverty line (BPL) card, $30 \%$ of the respondents were holding above the poverty line (APL) card and $3 \%$ of the respondents hold Annapurna Yojana Card in the affected villages. Similarly, $68 \%$ of the respondents were holding BPL cards, $32 \%$ of them holding APL card in the nonaffected villages.

\subsubsection{Social stratification}

About $62 \%$ of the respondents were from Backward Classes (BC), about 30\% were Most Backward Classes (MBC), $8 \%$ were Scheduled Castes (SC) and $1 \%$ of the respondents were from general category in the affected villages. On the other hand in the non-affected villages, about $66 \%$ of them were SCs, $26.5 \%$ were $\mathrm{BCs}$ and $8 \%$ of them were MBCs.

\subsection{The Landholdings of respondents in affected and non-affected villages}

Only $35.5 \%$ of the respondents were holding agricultural land in the affected villages compared to $51 \%$ of the respondents were holding agricultural land in non-affected villages. This gives an idea of how the affected villages had significantly lower landholding compared to that of non-affected villages.

\subsubsection{Details of landholding}

Among those who hold land (173) details of landholding are presented in Table 1. This clearly shows there is a similarity in landholding pattern in affected and non-affected villages. In fact the land holding in affected villages are higher in 1 to 2 acres and more than five acres categories. In total more people hold land (102) in non-affected villages compared to affected villages (71) out of 173. This indicates clearly there exist an imparity in terms of landholding that points to the problem of holding agricultural land.

\subsubsection{Type of ownership on landholding}

Further, a question on the kind of ownership of the land was asked among the 173 respondents in affected and non-affected villages. A total of 140 respondents cultivated on their land. Of those cultivated, 53 were from the affected villages and 87 were from the non-affected villages. In total, 26 respondents did not cultivate in their land. Of those, 15 were from the affected villages and 11 were from the non-affected villages. A total of 4 respondents have leased their land to others, of those, one 
respondent was from the affected village and 3 were from the non-affected villages. There was a respondent who cultivated in the leased land in the non-affected village and 2 in the affected villages had cultivated on a partnership basis.

\subsubsection{Irrigation of land}

A question on whether the agricultural land held by them was irrigated; out of 71 landholders in the affected villages 27 have irrigated their land. While in the non-affected villages, out of 102 landholders, 67 have irrigation their land.

\subsubsection{Type of crops cultivated}

To understand the type of crop cultivated among those who hold land, the following were reported (Please refer Table 2). Out of 84 cultivating farmers, 39 in affected villages and 45 in non-affected villages cultivated cereals crops such as, corn or maize, legumes, black gram. In the remaining, 19 in affected villages and 16 in non-affected villages cultivated vegetable or fruit. There were 10 in affected and 25 in non-affected villages raised trees. Seven in affected and 30 in non-affected villages cultivated flowers. There were 37 farmers in the non-affected villages cultivated paddy and 15 in affected villages engaged in cotton cultivation. There were 13 in affected and 12 in non-affected villages did not use their land for any cultivation.

\subsubsection{Land classification}

Based on the standard (wasteland, grazing land, grove land, sown land, and current barren land) land classification, the following were found in the study villages. There were no forest land, non-agricultural use land, and arable wasteland in the study villages. There was a grazing land in the non-affected village and wasteland only in the affected village. There were 54 in affected villages and 91 in non-affected villages sown their lands, and there were 6 in the affected villages and 12 in the non-affected villages had grove lands.

\subsubsection{Duration of cultivation}

In response to a question on whether they are cultivating thei agricultural land all through the year, it was found that out of 71 agricultural land holders in the affected villages only about $33 \%$ of them cultivated their land throughout the year. On the other than out of 102 agricultural land holders in the non-affected villages, about $62 \%$ have cultivated their land throughout the year. The less number of land holders cultivate in the affected villages compared to the non-affected villages is contributed to the problems associated with the pollution.

\subsection{Sources of Water and Pollution}

Table 3 presents the different sources of water used for household activities in the study villages. Out of 189 who accessed tap water through multiple sources, 94 were in the affected villages and 95 were in the 
non-affected villages. Out of those 143 respondents who had accessed water through one tap or hand pump, 43 were from affected villages and 100 were from non-affected villages. There were also 121 people reported to have paid for the water. Among the people who bought water, 89 were in the affected villages and 32 were in the non-affected villages. There were 70 in the affected villages and 21 in the nonaffected villages had tap water connection at their home connecting to bathroom, kitchen, and toilet. There were 59 respondents in the affected villages and 21 respondents in the non-affected villages had a water connection connected to a nearby dam. Out of 19 respondents who depend on well water or stream or lake or a bore well, 13 were from affected and 6 were from non-affected villages.

\subsubsection{Pollution and water contamination}

There were $72 \%$ in affected and $32 \%$ in non-affected villages reported that the water consumed by them was polluted. The types of changes experienced due to water pollution are as follows. Changes in the quality of water in terms of tastelessness of water was reported by 128 in the affected villages and 64 in the non-affected villages, while 81 in the affected villages and 18 in the non-affected villages reported salinity or deposits of salt in the water. Thirteen respondents in the affected villages and 6 in the nonaffected villages experienced itching while washing the skin using water. Only in the affected villages some people (8) have reported green deposits floating on the water surface and some (11) have reported foul smell in the surroundings. Eight of the affected village respondents quoted an unexplainable water quality caused by tannery pollution. There were also 3 respondents from the non-affected villages experienced industrial pollution caused water contamination by the other non-tannery industries. Overall there are more problems found in the closer to the tanneries than the farther villages. The problems such as green deposits caused by the tannery wastes and foul smell are evident that it is unique only to the tanneries.

\subsubsection{Pollution of Environment}

The environment surrounding of villages that were polluted higher (130) in the affected villages compared to the non-affected villages (9). While responding to the reasons, the number of reasons was reported as discussed in the following sections.

\subsubsection{Polluted Water Sources}

Among 139 who have reported their water sources were polluted, 115 of them in affected and 2 in nonaffected villages have said the water storage surrounding the border areas of the villages were polluted (Table 4). Additionally the table 4 clearly shows most of the water sources are polluted in the affected village compared to the non-affected village. In the non-affected villages, only 7 or less respondents have reported any of the above mentioned type of pollution of water sources in their villages. This clearly shows how the water sources surrounding the tanneries in the affected villages were more polluting than non-affected villages.

\subsubsection{Recognizable Changes in Water sources due to industrial pollution}


The Recognizable Changes in Water sources due to industrial pollution in the study villages are shown in the table 5. Most of the problems are significantly higher in affected villages compared to the nonaffected villages. Only the characteristics of without any attribute such as salt or colour are reported higher in the non-affected villages clearly shows the impact of tannery pollution on the water sources in the affected villages. The common characteristics reported in water sources due to industrial pollution are, salt deposits, change in colour, well water turned to black in colour, green colour particles floating on the surface, and tannery effluents mixing with the ground water. In addition, more people in affected also reported of dried up water sources. There were 25 respondents from affected villages and 12 respondents from non-affected villages said there are unexplainable changes in their surroundings. Overall, the affected villages located in and around the tanneries experiencing larger problem of pollution than the non-affected villages. This clearly shows how the rural environment is affected due to the tannery pollution.

\subsection{Problems faced due to industrial pollution}

Table 6 shows the type of difficulties faced by the respondents from affected and non-affected villages. There were 167 from the affected villages and 101 from the non-affected villages reported to have faced problems in getting drinking water in their villages. While mentioning about other problems related water, 109 in affected villages and 113 in non-affected villages experienced lack of sufficient water for agriculture. While, 88 in affected villages and 22 in non-affected villages have reported that there was a non-availability of clean water in their villages. While 37 in affected villages and 2 in non-affected villages reported to have an experience of not having a clean air in their villages. Only in the affected villages, there were 105 respondents who have reported an odour caused by the tanneries during monsoon seasons. There were also people reported rashes and itching experiences mostly (29) from the affected villages. In terms of employment status, the affected villages relatively lesser (82) problem of lack of jobs compared to that of non-affected villages (107). Similarly the transportation problem was more (156) in non-affected villages which farther from the town compared to affected villages (66) closer to the Dindigul town. There were more than 90 persons reported job losses due to Covid19 outbreak in both the villages.

Further, villagers were asked whether problems mentioned in Table 6 is caused by Tanneries. There were 107 of the respondents from the affected villages and 26 of the respondents from the non-affected villages mentioned that the problems mentioned in Table 6 are caused by tanneries (Table 7). There were 62 respondents from the affected villages and 43 respondents from the non-affected villages were not sure whether the problems are caused by the tanneries.

\subsubsection{Other problems caused by industrial pollution}

A question on what are other problems caused by industrial pollution, the problems such as skin diseases, fever, dental problems, hair loss, looking older, skin wrinkles, land become uncultivable, rashes and itching in body, overall deterioration of health, and livelihood been affected were reported. It is clear 
from the Figure 1 that all the reported problems were higher in the affected villages compared to the nonaffected villages.

\subsection{Impact of water pollution on livelihood}

\subsubsection{Water Pollution on the Households and the Community}

In response to a question on whether there was an impact of water pollution on the Households and the Community, 145 from the affected villages and 9 from the non-affected villages were opined with that. Table 8 shows out of those 154 respondents, many (113) from the affected villages felt it is difficult even to walk in neighbourhood their villages due to tannery pollution. Other major problems reported in the affected villages are the villages are no longer liveable and their livelihood has been affected. The nonaffected villages had lesser problems according to the respondents. There was also a unique problem reported by the villages near tanneries was they have not been visited by their friends and relatives due to the smell and poor environment in their villages.

\subsubsection{Water pollution affected the livestock and caused other problems}

About $60 \%$ of the respondents in the affected villages reported that the polluted water had affected livestock and caused other problems. Only $5 \%$ of the respondents from the non-affected villages reported the same. Table 9 shows many of the problems related to livestock and other problems are higher in affected villages than the non-affected villages. The reduction in quantity of milk was reported in the affected villages more than the non-affected villages. Similarly, the problems such as increase in Mosquitoes, emergence of newer diseases were reported very in affected villages. People also feel there is a nutritional related problem due to the consumption of polluted water in the affected villages. This clearly shows how the villages surrounding the tannery pollution suffer due to various problems.

\subsection{Impact of water pollution on Agriculture}

\subsubsection{Impact of Water Pollution on Agriculture}

When the respondents were asked whether water pollution affected the agriculture, 125 in the affected villages and 10 in the non-affected villages felt their agriculture was affected. Table 10 shows various reasons quoted on how the water pollution has affected the agriculture in the study villages. The problems such as reduction in agricultural production, irrigation sources were polluted, farmland become infertile, poor quality of produce were major problems reported. They were also finding it difficult to sell their land due to pollution. In general the above problems were reported very low in non-affected villages.

\subsubsection{Impact of water pollution on soil}

Further a question on whether the water pollution affects the soil, 148 in affected villages and 13 in nonaffected villages said their soil been affected. Out of 161 respondents reported the polluted water affected their soil, more than 100 respondents in the affected villages reported that the soil quality was 
deteriorated and the soil was polluted due to the industrial effluents. That was followed by reasons such as 90 reported agricultural yields were reduced, 85 respondents reported soil nutrients were deteriorated, 59 respondents reported soil became saline-alkaline, 57 respondents reported the soil was unfit for cultivation, and 8 respondents reported unexplainable reasons. This was lower in the non-affected villages with only 13 respondents have reported the soil was polluted due to industrial effluents, which was followed by 12 respondents reporting deterioration in soil quality and soil nutrients, 8 respondents reported soil is unfit for cultivation, and 7 respondents reported agricultural yields reduced. In general even the polluted soil in the affected villages due to tannery pollution is highly recognised by the respondents of the study.

\section{Discussion}

To understand the difference in economic status authors looked in to the difference between mean income of affected and non-affected. It was found the income between the villages was significantly different and it was high among the affected villages due their vicinity to the urban centre. When analysed more in to the employment status it found that most of them were engaged in multiple professions in different part of the year as the primary activities they were engaged in were seasonal in nature. In terms of landholding, affected villages had significantly lower landholding compared to that of non-affected villages. This is further suggestive of problems in holding agricultural land due to pollution. In terms of irrigation of their agricultural land one third of the affected villages and two thirds of the nonaffected villages have irrigated their land. This is also confirming with the point that the water they have was polluted and they were not able irrigate their agricultural land. This lead to less number of land holders cultivate in the affected villages compared to that of non-affected villages. Study by Shah et al, 2021 too reported the Industrial pollution adversely impacts the environment(Shah, SN. Manzoor, S. and Asim 2021).

Related to the water they consumed it was found that three fourth in affected villages and one third in the non-affected villages reported that the water they consumed was polluted. In general, there were more problems reported in the villages closer to the tanneries than the farther ones. In the affected villages people further mentioned about green deposits formed on the surface of water polluted by the tannery waste and foul smell. It is clearly evident from the villagers live in and around tanneries face stringent water problems due to pollution. This also affects their surrounding environment. The water sources in general in the villages surrounding the tanneries were polluted. They further given details on the recognizable changes happened in the water sources due to the tannery pollution. The villages located in and around the tanneries experienced bigger problem of pollution compared to the non-affected villages. The comparison gives a clear distinction between the villages near tanneries and farther from tanneries. The further reiterated different problems included drinking water contamination. The problems such as non-availability of clean air, odour due to tannery effluents mixing with open drainage, and rashes and itching experienced by the population. They were undoubtedly relating these problems with the pollution due to tanneries in their vicinity. Only advantage the people live near tanneries was that of having better transportation facilities compared to the other villages. These findings are in agreement with a study 
from industrial area of Panipat city, India found untreated industrial effluents can cause an environmental threat to ground water resources(Bharti, Kumar, and Singh 2013).

There different problems that were reported high especially in the villages closer to tanneries prevalence of skin diseases, fever, and dental problems, experiencing hair loss, people feel they are looking older than their age, having wrinkled skin, experiencing rashes and itching in body, feeling the overall deterioration of their health, land was contaminated and become uncultivable, and adverse effect on livelihood of the population. Problems similar to that were reported in a study conducted in Panipat, India(Bharti, Kumar, and Singh 2013).

The people from the affected villages reported that it was difficult for them to walk around in their neighbourhood because of tannery pollution. They further stated the villages have become unliveable and their livelihood was affected. This was less among the villagers from the non-affected villages. A unique problem stated by the respondents of the affected villages was their friends and relatives were hesitant to visit them due to the smell and poor environmental conditions caused by the tannery pollution. The effect of industrial pollution on livelihood was in agreement with a study from Nigeria that found a significant relationship between perceived effect of industrial water pollution and the livelihood activities of rural dwellers(Oluseyi, Oluseun, and Birdie 2011).

Many in the affected villages reported the tannery pollution had affected livestock and caused other problems. Similar findings were reported in a study from the state of Assam in India(Mech and Hazarika 2018). The same study found that how a Polymer company discharged the polluted effluents to the Sessa river that in turn polluted the water and that deteriorated the aquatic plants and animals that ultimately disrupted the livelihood of fishermen in that region(Mech and Hazarika 2018).

The present study finding further went in to the details such as reduction in quantity of milk as one of the effect of tannery pollution on their livelihood. The industrial pollution adversely affect the livelihood of the population(Oluseyi, Oluseun, and Birdie 2011).

Similarly, the problems such as increase in Mosquitoes, emergence of newer diseases were reported very in affected villages. People also feel there is a nutritional related problem due to the consumption of polluted water in the affected villages. This is similar to that of the findings from a study from Nigeria reported that the persistence of pollutant in the water cause long term health problems(Dan'azumi and Bichi 2010). This clearly shows how the villages surrounding the tannery pollution suffer due to various problems. More than half in the affected villages and very few in the non-affected villages felt their agriculture was affected by the water pollution. The reasons that were stated for the effect of water pollution on the agriculture in the study villages uncovered various problems such as reduction in agricultural production, polluted irrigation sources, farmland become infertile due to pollution, and pollution leading to poor quality of produce. Even they decide to sell their land, it is difficult for them to sell their land as they were already polluted by the tannery effluents. Very few have reported the above problems from the non-affected villages. This finding is in agreement with a study conducted in Panipat, India observing heavy metals presence in ground water used for irrigated agricultural soil that transferred 
them from effluent to ground water(Bharti, Kumar, and Singh 2013). The industrial effluents cause environmental threat to ground water resources and deteriorate the soil quality and ultimately the agricultural productivity(Bharti, Kumar, and Singh 2013). Further it is important to note about three fourth in the affected villages and a very few in non-affected villages said their soil been affected by the pollution. The soil pollution lead to reduction in agricultural yields, deterioration in soil nutrients, soil became saline-alkaline, soil was unfit for cultivation. This was lower in the non-affected villages. These problems are in confirmation with the study by Bharti et al. 2013. The common people were able to recognize the polluted soil in the affected villages due to tannery pollution with their naked eye suggests the problem very obvious and not recognized by the policy makers and politicians may be due to diverse economic interests(Reddy and Behera 2006). Even the interference of Courts that followed the polluterpays approach to agriculture was likely to be infeasible and one should put efforts on including elements of the polluter-pays approach that is incorporated into agricultural water quality policy(Shortle et al. 2012). Even the court proceedings that is in response to the Farmers demanding for more compensation shows there need to be more efforts on resolving the issue(Court 2014).

\section{Conclusion}

This clearly shows in spite of the problem that is clearly evident from the naked eye are ignore by the policy makers and politicians due to different interests of the institutions they belong to. The first author of the study has studied the same problem in 1990 as his Master's dissertation is heartened to find the problem is still not been solved even after 30 years of his earlier study. Only the magnitude of the problem has reduced a bit but did not help the villagers who live in and around the tanneries. The efforts such as construction of Common Effluent Plant and paying compensation did not solve the problem. Even the court intervention on closing some of the units did not positively contributed to improvement in the quality of water and in turn did not improve the livelihood of the population live in those villages. A debate on environmental pollution and economic benefits did not prove its merits that are clearly evident from the findings of this paper. Even after 30 years, the problem of tannery pollution still in its place and it is adding its adverse effects on the livelihood of the population in Dindigul.

\section{Declarations}

\section{Acknowledgements}

Authors acknowledge the support of project cell of Sree Chitra Tirunal Institute of Medical Science and Technology, and Indian Council for Social Science Research for funding the study. Authors would like to thank two investigators, Mr Diraviam P and Ms Mohanalakshmi R and all the villagers from 20 study villages for their cooperation in data collection.

\section{Declarations}

\section{Acknowledgement:}


Funding: This work was supported by the Indian Council for Social Science Research, New Delhi (IMPRESS/P357/417/2018-19/ICSSR).

\section{Authors' contributions:}

Srinivasan Kannan conceived the study. Srinivasan Kannan wrote the article. Srinivasan Kannan engaged in tool development, analysis, draft writing, final proof reading.

Rengasamy Karuppaiah, Engaged in data collection, data analysis, draft writing.

Ethics approval and consent to participate: Sree Chitra Tirunal Institute for Medical

Sciences and Technology Institutional Ethics Committee (SCT/IEC/1495/OCOTBER-2019) granted ethical approval. All participants will be provided with a written informed consent before the study.

\section{Abbreviations}

BPL Below Poverty Line

APL Above Poverty Line

SC Scheduled Caste

OBC Other Backward Classes

MBC Most Backward Classes

INR Indian Rupee

\section{References}

Agenda, Global. 2016. "Global Agenda Blueprints for a Greener Footprint Sustainable Development at a Landscape Scale," no. January. http://www3.weforum.org/docs/WEF_Blueprint_for_a_Greener.pdf.

Asha, Krishnakumar. 2002. "An Award and a Pledge." Frontline, 2002.

https://doi.org/10.1093/ptj/45.9.838.

Bharti, Pawan K, Pawan Kumar, and Vijender Singh. 2013. "Impact of Industrial Effluents on Ground Water and Soil Quality in the Vicinity of Industrial Area of Panipat City, India." Journal of Applied and Natural Science 5 (1 SE-): 132-36. https://doi.org/10.31018/jans.v5i1.294.

Choudhuri, Pallavi, and Sonalde Desai. 2021. "Lack of Access to Clean Fuel and Piped Water and Children's Educational Outcomes in Rural India." World Development 145 (July): 105535. https://doi.org/10.1016/j.worlddev.2021.105535. 
Commission, Election. n.d. "Voters List." https://www.elections.tn.gov.in/.

Court, Madras High. 2014. "Vellore Citizens Welfare Forums vs Union Of India Rep. By Its ... on 9 September, 2014." 2014. https://indiankanoon.org/doc/182731848/.

Dan'azumi, Salisu, and Mustapha Hassan Bichi. 2010. "Industrial Pollution and Implication on Source of Water Supply in Kano, Nigeria." International Journal of Engineering \& Technology 10 (1): 101-9.

Ercin, Ertug. 2018. Overuse of Water Resources: Water Stress and the Implications for Food and Agriculture. Encyclopedia of Food Security and Sustainability. Elsevier. https://doi.org/10.1016/B978-008-100596-5.21998-7.

Fu, Chuan, Yuan Cao, and Jacqueline Tong. 2020. "Biases towards Water Pollution Treatment in Chinese Rural areas-A Field Study in Villages at Shandong Province of China." Sustainable Futures 2 (July): 100006. https://doi.org/10.1016/j.sftr.2019.100006.

Kähkönen, Satu. 1999. "Does Social Capital Matter in Water and Sanitation Delivery?" Social Capital Initiative Working Paper Series, no. 9: 1-45. http://www.worldbank.org/socialdevelopment.

Kannan, Srinivasan. 2020. "Social, Economic and Health Impact of Industrial Pollution in Dindigul District, Tamil Nadu." Social Science Protocols 3 (December): 1-7. https://doi.org/10.7565/ssp.v3.4914.

Klaus, Schwab(World Economic Forum). 2016. "The Global Risks Report 2016." Geneva. http://www3.weforum.org/docs/GRR/WEF_GRR16.pdf.

Kulinkina, Alexandra V, Michelle O Sodipo, Olivia L Schultes, Bernard G Osei, Emmanuel A Agyapong, Andrey I Egorov, Elena N Naumova, and Karen C Kosinski. 2020. "Rural Ghanaian Households Are More Likely to Use Alternative Unimproved Water Sources When Water from Boreholes Has Undesirable Organoleptic Characteristics." International Journal of Hygiene and Environmental Health 227 (July): 113514. https://doi.org/10.1016/j.ijheh.2020.113514.

Lund, Jay R. 2015. "Integrating Social and Physical Sciences in Water Management." Water Resources Research 51 (8): 5905-18. https://doi.org/https://doi.org/10.1002/2015WR017125.

Mallick, Bishawjit, and Luisa Fernanda Roldan-Rojas. 2015. "Social Stratification in the Drinking Water Scarcity Context: Empirical Evidence of Coastal Bangladesh." American Journal of Water Resources 3 (3): 92-99. https://doi.org/10.12691/ajwr-3-3-4.

Mamuye Bayu, Fikadu. 2018. "Evaluation of Environmental and Social Impacts of Flour Factory: A Case of Kedija Flour Factory, Werabe, Ethiopia Citation: Fikadu Mamuye Bayu (2018) Evaluation of Environmental and Social Impacts of Flour Factory: A Case of Kedija Flour Factory, Werabe, " 1 (1): 1-8. .

Mech, Annesha, and Parinita Hazarika. 2018. "A Study on the Impact of Industrial Effluents on Local Ecosystem and Willingness to Pay for Its Restoration." Amity Journal of EconomicsAJECOADMAAAmity 
Journal of Economics 3 (1): 61-74. https://amity.edu/UserFiles/admaa/61185Paper 5.pdf.

Meier, Wilbur L. 1977. "No Title." In Climate, Climatic Change, and Water Supply, edited by Geophysics Research Panel on Water and Climate, Geophysics Study Committee and National Research Council Board, 85-96. Washington, D.C.: NATIONAL ACADEMY OF SCIENCES. https://doi.org/10.17226/185.

Mekuria, Deshu Mamo, Alemnew Berhanu Kassegne, and Seyoum Leta Asfaw. 2021. "Assessing Pollution Profiles along Little Akaki River Receiving Municipal and Industrial Wastewaters, Central Ethiopia: Implications for Environmental and Public Health Safety." Heliyon, July, e07526. https://doi.org/10.1016/j.heliyon.2021.e07526.

Oluseyi, Adebowale, Adebowale Oluwawemimo Oluseun, and Oyesola Olutokunbo Birdie. 2011. "Perceived Effect of Industrial Water Pollution on the Livelihood of Rural Dwellers in Yewa Area, Ogun State, Nigeria." European Journal of Social Sciences 22 (1): 66-75.

Random.org. n.d. "RANDOM.ORG Randomnessand IntegrityServices Ltd." https://www.random.org/. Reddy, V Ratna, and Bhagirath Behera. 2006. "Impact of Water Pollution on Rural Communities: An Economic Analysis." Ecological Economics 58 (3): 520-37.

https://doi.org/10.1016/j.ecolecon.2005.07.025.

Schulte, Peter., and Jason(Pacific Institute) Morrison. 2014. "Driving Harmonization of Water-Related Terminology Discussion Paper."

Shah, SN. Manzoor, S. and Asim, M. 2021. "IMPACT OF INDUSTRIAL POLLUTION ON OUR SOCIETY." Pakistan Journal of Science 73 (1): 222-29.

Shortle, James S, Marc Ribaudo, Richard D Horan, and David Blandford. 2012. "Reforming Agricultural Nonpoint Pollution Policy in an Increasingly Budget-Constrained Environment." Environmental Science \& Technology 46 (3): 1316-25. https://doi.org/10.1021/es2020499.

TNSPCB. n.d. "Tamil Nadu Pollution Control Board." https://dindigul.nic.in/departments/tamil-nadupollution-control-board/.

Trust, Seeds. n.d. "TANNERY POLLUTED AREA AT DINDIGUL." http://seedstrust.org.in.

Veiga, Marcelo Motta, Dalton Marcondes Silva, Lilian Bechara Elabras Veiga, and Mauro Velho De Castro Faria. 2006. "Pesticide Pollution in Water Systems in a Small Rural Community in Southeast Brazil." Cadernos de Saude Publica 22 (11): 2391-99. https://doi.org/10.1590/s0102-311x2006001100013.

Walker, Warren E, Daniel P Loucks, and Gemma Carr. 2015. "Social Responses to Water Management Decisions." Environmental Processes 2 (3): 485-509. https://doi.org/10.1007/s40710-015-0083-5. 
Wang, Mark, Michael Webber, Brian Finlayson, and Jon Barnett. 2008. "Rural Industries and Water Pollution in China." Journal of Environmental Management 86 (4): 648-59.

https://doi.org/10.1016/j.jenvman.2006.12.019.

Zhou, Li, Ling-zhi Li, and Ji-kun Huang. 2021. "The River Chief System and Agricultural Non-Point Source Water Pollution Control in China." Journal of Integrative Agriculture 20 (5): 1382-95.

https://doi.org/10.1016/S2095-3119(20)63370-6.

\section{Tables}

Table 1. Land Acres details of Household Members.

$\mathrm{N}=173$

\begin{tabular}{|c|c|c|c|c|}
\hline \multicolumn{5}{|c|}{ Land Acres details of Household Members } \\
\hline & & $\begin{array}{l}\text { Affected } \\
\text { Villages }\end{array}$ & $\begin{array}{l}\text { Non-Affected } \\
\text { Villages }\end{array}$ & Total \\
\hline \multirow{12}{*}{$\begin{array}{l}\text { Land Acres details of Household } \\
\text { Members }\end{array}$} & \multirow[t]{2}{*}{$<1$} & 23 & 33 & 56 \\
\hline & & $32.39 \%$ & $32.35 \%$ & $32.37 \%$ \\
\hline & \multirow{2}{*}{$\begin{array}{l}1.01- \\
2\end{array}$} & 31 & 26 & 57 \\
\hline & & $43.66 \%$ & $25.49 \%$ & $32.95 \%$ \\
\hline & \multirow{2}{*}{$\begin{array}{l}2.01 \\
-3\end{array}$} & 8 & 17 & 25 \\
\hline & & $11.27 \%$ & $16.67 \%$ & $14.45 \%$ \\
\hline & \multirow{2}{*}{$\begin{array}{l}3.01- \\
4\end{array}$} & 6 & 18 & 24 \\
\hline & & $8.45 \%$ & $17.65 \%$ & $13.87 \%$ \\
\hline & \multirow{2}{*}{$\begin{array}{l}4.01- \\
5\end{array}$} & 0 & 5 & 5 \\
\hline & & $0 \%$ & $4.90 \%$ & $2.89 \%$ \\
\hline & \multirow[t]{2}{*}{$>5$} & 3 & 3 & 6 \\
\hline & & $4.23 \%$ & $2.94 \%$ & $3.47 \%$ \\
\hline \multicolumn{2}{|l|}{ Total } & 71 & 102 & 173 \\
\hline
\end{tabular}

Table 2 Cropping Pattern

$N=173$ 


\begin{tabular}{|llll|}
\hline Cropping pattern & Affected & & \\
\hline villages & $\begin{array}{l}\text { Non-Affected } \\
\text { villages }\end{array}$ & Total \\
\hline Paddy & 0 & 27 & 27 \\
\hline $\begin{array}{l}\text { Cereals (Corn, Rye, Maize, Legumes, Black } \\
\text { Gram) }\end{array}$ & 39 & 45 & 84 \\
\hline Vegetables / Fruits & 19 & 16 & 35 \\
\hline Trees & 10 & 25 & 35 \\
\hline Flowers & 7 & 30 & 37 \\
\hline Cotton & 15 & 0 & 15 \\
\hline Not cultivated & 13 & 12 & 25 \\
\hline
\end{tabular}

Table 3 Source of Waters for Household Activities

$\mathrm{N}=400$

\begin{tabular}{|lllc|}
\hline Source of Waters for Household Activities & $\begin{array}{l}\text { Affected } \\
\text { Villages }\end{array}$ & $\begin{array}{l}\text { Non-Affected } \\
\text { Villages }\end{array}$ & Total \\
\hline $\begin{array}{l}\text { Tap Water Connecting the House (Bathroom, } \\
\text { Kitchen, Toilet) }\end{array}$ & 70 & 21 & 91 \\
\hline $\begin{array}{l}\text { Ground water using well / stream / lake Water/ bore } \\
\text { well }\end{array}$ & 13 & 6 & 19 \\
\hline One Tap / Hand Pump outside the House & 43 & 100 & 189 \\
\hline Water Supply System through Multiple Taps & 94 & 95 & 80 \\
\hline Dam water connection pipe & 59 & 21 & 121 \\
\hline Buying water for Money & 89 & 32 & 143 \\
\hline
\end{tabular}

Table 4 Types of Water Sources that are reported to have been Polluted

\section{$\mathrm{N}=139$}




\begin{tabular}{|llll|}
\hline $\begin{array}{l}\text { Types of Water Sources that are Reported to the } \\
\text { Polluted by the Villages }\end{array}$ & $\begin{array}{l}\text { Affected } \\
\text { Villages }\end{array}$ & $\begin{array}{l}\text { Non-Affected } \\
\text { Villages }\end{array}$ & Total \\
\hline Water logging surrounding the tube wells & 11 & 6 & 17 \\
\hline Ponds & 62 & 0 & 62 \\
\hline Borders of the villages & 115 & 2 & 117 \\
Well & 35 & 5 & 40 \\
\hline Agricultural land & 32 & 7 & 39 \\
\hline
\end{tabular}

Table 5 Recognizable Changes in Water sources due to industrial pollution

$\mathrm{N}=400$

\begin{tabular}{|llll|}
\hline Recognized Changes in Water sources & Affected Villages & Non-Affected Villages & Total \\
\hline Water dried up & 84 & 18 & 102 \\
\hline Salt deposits & 73 & 21 & 94 \\
\hline Green colour particles floating on the water & 39 & 0 & 39 \\
\hline Changes of colour in the water & 46 & 1 & 47 \\
\hline Well waters turned black & 41 & 4 & 45 \\
\hline Tannery effluents mixes with the water sources & 38 & 0 & 38 \\
\hline Without any attribute & 21 & 175 & 37 \\
\hline Unexplainable & 25 & 12 & \\
\hline
\end{tabular}

Table 6 Difficulties caused by industrial pollution

$\mathrm{N}=400$ 


\begin{tabular}{|llll|}
\hline Difficulties experienced & $\begin{array}{l}\text { Affected } \\
\text { Villages }\end{array}$ & $\begin{array}{l}\text { Non-Affected } \\
\text { Villages }\end{array}$ & Total \\
\hline Problem related drinking water & 167 & 101 & 268 \\
\hline Lack of water for agriculture & 109 & 113 & 222 \\
\hline Non availability of cleanly air & 37 & 2 & 39 \\
\hline Non availability of clean water & 88 & 22 & 110 \\
\hline $\begin{array}{l}\text { Odour caused by tannery sewage during rainy } \\
\text { season }\end{array}$ & 105 & 0 & 105 \\
\hline Rashes and Itching experienced the body & 29 & 2 & 31 \\
\hline Lack of job opportunities & 82 & 107 & 189 \\
\hline No Transportation Facilities & 66 & 156 & 222 \\
\hline Job loss caused by Corona & 94 & 98 & 192 \\
\hline
\end{tabular}

Table 7 Reasons for the Problems

$\mathrm{N}=400$

\begin{tabular}{|lllr|}
\hline Reasons & $\begin{array}{l}\text { Affected } \\
\text { Villages }\end{array}$ & $\begin{array}{l}\text { Non-Affected } \\
\text { Villages }\end{array}$ & Total \\
\hline Problems caused by tanneries & 107 & 26 & 133 \\
\hline Not problems caused by tanneries & 31 & 131 & 162 \\
\hline $\begin{array}{l}\text { Not aware whether they are caused by } \\
\text { Tanneries }\end{array}$ & 62 & 43 & 400 \\
\hline Total & 200 & 200 & \\
\hline
\end{tabular}

Table 8 Effect of Pollution on livelihood

$\mathrm{N}=154$ 


\begin{tabular}{|lllc|}
\hline Effect of Pollution on Society & $\begin{array}{l}\text { Affected } \\
\text { Villages }\end{array}$ & $\begin{array}{l}\text { Non-Affected } \\
\text { Villages }\end{array}$ & Total \\
\hline Not liveable & 54 & 1 & 55 \\
\hline Not fit to walk in the neighbourhood & 113 & 0 & 113 \\
\hline $\begin{array}{l}\text { The friends and relatives avoid visiting the } \\
\text { villagers }\end{array}$ & 9 & 0 & 9 \\
\hline Livelihood affected & 88 & 9 & 97 \\
\hline Unexplainable problems & 3 & 1 & 4 \\
\hline
\end{tabular}

Table 9 Water pollution on livestock and other problems

$\mathrm{N}=128$

\begin{tabular}{|llll|}
\hline Problems & $\begin{array}{l}\text { Affected } \\
\text { Villages }\end{array}$ & $\begin{array}{l}\text { Non-Affected } \\
\text { Villages }\end{array}$ & Total \\
\hline Reduction in the quantity of milk by the live stocks & 54 & 10 & 64 \\
\hline Increase in the Mosquitoes breeding & 108 & 5 & 113 \\
\hline Newer diseases spread in the community & 110 & 8 & 118 \\
\hline Difficult to sell lands as they are polluted & 19 & 0 & 50 \\
\hline $\begin{array}{l}\text { People become malnourished and weakened by drinking } \\
\text { the polluted water }\end{array}$ & 42 & 8 & 4 \\
\hline \begin{tabular}{l} 
Unexplainable problems \\
\hline
\end{tabular}
\end{tabular}

Table 10 Reasons given for reporting water pollution affecting agriculture $\mathrm{N}=135$ 


\begin{tabular}{|lllc|}
\hline Reasons & $\begin{array}{l}\text { Affected } \\
\text { Villages }\end{array}$ & $\begin{array}{l}\text { Non-Affected } \\
\text { Villages }\end{array}$ & Total \\
\hline Reduction in the Agricultural Production & 101 & 8 & 109 \\
\hline $\begin{array}{l}\text { Tannery effluents enter in to the water sources such } \\
\text { as wells }\end{array}$ & 47 & 9 & 46 \\
\hline $\begin{array}{l}\text { Difficult to sell the Tannery Effluent Polluted } \\
\text { farmland }\end{array}$ & 4 & 0 & 108 \\
\hline Farmland become infertile & 98 & 10 & 87 \\
\hline Poor quality of agricultural produce & 82 & 5 & 13 \\
\hline Unexplainable problems & 13 & 0 & 4 \\
\hline
\end{tabular}

\section{Figures}

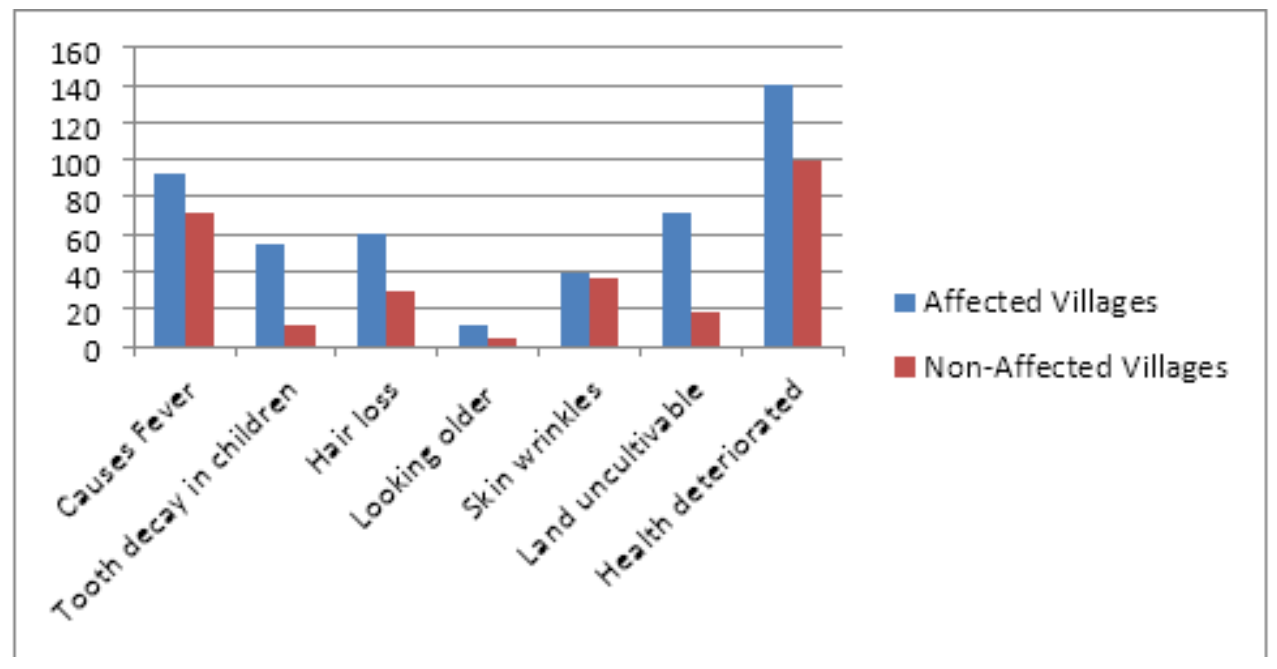

Figure 1

Other problems caused by industrial pollution. 